\title{
PENGARUH KUALITAS LAYANAN, PERSEPSI NILAI DAN KEPERCAYAAN TERHADAP KEPUASAN DAN LOYALITAS PENGGUNA LAYANAN MOBILE BANKING
}

\author{
Heri Setiawan \\ Jurusan Administrasi Bisnis Politeknik Negeri Sriwijaya \\ Jl.Srijaya Negara Bukit Besar Palembang, 30139 - Indonesia
}

\begin{abstract}
This study aims to determine the determinant of customer satisfaction and loyalty implications for users of mobile banking. This study used Structural Equation Modeling (SEM) to test the hypotheses of the study and use the software AMOS 5.0 and SPSS 20.0. The population in this study are the mobile banking users in seven banks in Palembang City; Bank Mandiri, Bank BNI, Bank BRI, Bank Danamon, Bank BCA, Bank Mega and Bank Permata. The research sample consist of 250 respondents to the provisions of the election to the mobile banking users. The results showed that the service quality, perceived value, trust and customer satisfaction has a strong effect on customer loyalty. Service quality have significant effect on consumer satisfaction. Perceived of value have significant effect on customer satisfaction. Trust have significant effect on consumer satisfaction. Service quality have significant effect on customer loyalty. Perceived of value have significant effect on customer loyalty. Trust have significant effect on customer loyalty. Customer satisfaction have significant effect on customer loyalty. Banks should build strong relationships with customers and provide better service quality to reduce the behavior of customers to switch to another bank service.
\end{abstract}

Keywords: service quality, perceived value, trust, satisfaction, customer loyalty

\section{PENDAHULUAN}

Perkembangan teknologi dan komunikasi saat ini telah menciptakan berbagai jenis dan peluang bisnis baru dimana setiap transaksi bisnis semakin banyak dilakukan secara elektronik. Sehubungan dengan perkembangan teknologi dan komunikasi tersebut memungkinkan setiap orang dengan mudah melakukan perbuatan hukum seperti transaksi melakukan jual-beli dengan orang lain. Perkembangan teknologi dan komunikasi memang cepat dan memberi pengaruh signifikan dalam segala aspek kehidupan kita. Penggunaan teknologi dan komunikasi tidak hanya terbatas pada pemanfaatan informasi yang dapat diakses melalui jaringan

Korespondensi dengan Penulis:

Heri Setiawan. HP +6281273439567

e-mail: setyawanhery@yahoo.com 
Pengaruh Kualitas Layanan, Persepsi Nilai dan Kepercayaan...

Heri Setiawan

komunikasi untuk melakukan komunikasi, melainkan juga dapat digunakan sebagai sarana untuk melakukan transaksi perbankan.

Perbankan di Indonesia saat ini telah mengikuti perkembangan teknologi dan komunikasi. Mobile banking pada umumnya disebut m-banking yang merupakan sebuah sistem layanan dari sebuah lembaga keuangan seperti bank untuk melakukan sejumlah transaksi keuangan yang dapat diakses langsung oleh nasabah melalui perangkat mobile seperti telepon seluler. Fasilitas mobile banking adalah sebuah fasilitas dari bank dalam era modern ini yang mengikuti perkembangan teknologi dan komunikasi. Fasilitas mobile banking ini merupakan fasilitas dalam komunikasi yang bergerak dan diakses melalui telepon selular berbasis GSM. M-Banking digunakan dengan menu yang sudah tersedia di SIM Card yang saat ini menggunakan media short message service. Telepon seluler mempunyai kelebihan mampu bergerak (mobile) tanpa batas ruang dan waktu, juga memungkinkan manusia untuk berjalan dengan aktivitas yang sedang dijalankan.

Mobile banking mengacu pada sistem yang memungkinkan nasabah bank untuk mengakses rekening dan informasi umum tentang produk dan jasa bank melalui perangkat mobile dengan menggunakan SMS (Short Message Service). Seluruh jenis transaksi yang dulu manual kini bisa diselesaikan tanpa mengenal ruang dan waktu melalui dunia maya. Semua jenis layanan perbankan bisa dilakukan sendiri oleh nasabah seperti: cek saldo, melihat daftar mutasi, pemindah bukuan (transfer rekening), melakukan pembayaran kartu kredit, tagihan telepon dan handphone, listrik, tagihan air minum PDAM dan sebagainya kecuali yang langsung melibatkan uang tunai seperti penyetoran dan penarikan.

Di Indonesia, mobile banking telah diperkenalkan pada konsumen perbankan sejak beberapa tahun lalu. Berbagai bank, baik milik pemerintah atau swasta Indonesia telah menyediakan layanan mobile banking antara lain; Bank Mandiri, Bank BNI, Bank BRI, Bank BCA, Bank Danamon, Bank Mega dan Bank Permata. Fitur-fitur yang ditawarkan dalam layanan mobile banking secara umum adalah melihat saldo rekening dan riwayat transaksi, bunga deposito berjangka, pemindahan dana antar rekening, pemindahan dana ke rekening bank lainnya, pemindahan dana antar bank di Indonesia (SKN \& RTGS), pemindahan dana ke rekening di luar negeri, membaca dan mengirimkan pesan (yang dienkripsi demi keamanan nasabah) kepada bank, informasi nilai tukar mata uang asing dan tingkat suku bunga, otorisasi transaksi (khusus nasabah business banking), membayar tagihan (khusus nasabah business banking).

Dalam industri perbankan khususnya layanan mobile banking, elemen kunci dari kepuasan pelanggan adalah sifat hubungan antara pelanggan dan penyedia produk dan jasa yaitu bank. Produk dan kualitas layanan mobile banking biasanya dicatat sebagai prasyarat penting untuk memuaskan pelanggan dan mempertahankan nilai pelanggan. Dalam industri perbankan, pelanggan telah menempatkan kriteria kepuasan pelanggan terhadap kualitas layanan mobile banking yang disediakan oleh bank. Sebagai contoh: cepat dan efisien, kerahasiaan bank, kecepatan transaksi, akurasi tagihan, ketepatan waktu penagihan, kejelasan penagihan, biaya akses yang kompetitif, dan kualitas layanan merupakan faktor kunci yang secara signifikan mempengaruhi kepuasan pelanggan.

Kualitas layanan (service quality) mengacu pada harapan konsumen berdasarkan pengalaman dan reputasi suatu perusahaan. Kualitas layanan (service quality) berfungsi sebagai patokan untuk interpretasi kualitas layanan yang mencerminkan apakah kinerja pelayanan aktual telah sesuai atau gagal memenuhi harapan pelanggan. Berbeda dengan kualitas barang, kualitas layanan (service quality) adalah dimensi abstrak dan sulit dipahami (Cronin dan Taylor, 1992) karena fitur yang unik untuk layanan: intangibility, inseparability, hetero- 


\section{Jurnal Keuangan dan Perbankan | PERBANKAN}

Vol. 20, No.3, September 2016: 518- 528

genitas, dan tidak merusak produksi dan konsumsi. Kualitas layanan (service quality) mempengaruhi kepuasan pelanggan serta nilai-nilai pelanggan dan dengan demikian mempengaruhi loyalitas pelanggan (Zeithaml et al., 1996).

Cronin dan Taylor (1992) mengidentifikasi kualitas pelayanan sebagai anteseden kepuasan dan berpendapat bahwa kualitas layanan (service quality) memiliki dampak yang lebih rendah pada niat dibandingkan dengan kepuasan konsumen. Kepuasan pelanggan yang menerima layanan juga melibatkan jalinan hubungan, dan semua jenis hubungan membutuhkan kepercayaan. Selain itu, penelitian sebelumnya telah mengidentifikasi bahwa kepercayaan merupakan salah satu faktor penentu dari loyalitas pelanggan (Aydin dan Ozer, 2005).

Park et al., (2006) mengamati bahwa konsumen selalu mempertimbangkan sejauh mana menerima nilai dari uang yang dikeluarkan dalam memutuskan apakah akan kembali ke penyedia layanan atau tidak. Persepsi nilai telah mendapat perhatian sebagai konstruk yang stabil untuk memprediksi perilaku pembelian (Anderson dan Srinivasan, 2003). Selain itu, persepsi nilai pelanggan telah ditemukan dapat meningkatkan kesediaan konsumen untuk membeli dan mengurangi niat konsumen mencari alternatif. Penelitian Roig et al., (2006) menemukan bahwa nilai hanya dirasakan oleh pelanggan, dan tidak dapat ditentukan secara obyektif oleh penjual. Persepsi nilai pelanggan secara positif berkaitan dengan loyalitas pelanggan (Sirdeshmukh et al., 2002). Terdapat hubungan yang kuat antara persepsi nilai dengan niat dimasa depan (Kuo et al., 2009). Dalam penelitian yang dilakukan oleh Atalik dan Arslan (2009) menemukan bahwa penciptaan nilai kepada pelanggan berdampak kepada loyalitas. Kemudian, dalam sebuah penelitian oleh Lai et al., (2009) menemukan bahwa persepsi nilai merupakan salah satu faktor yang berpengaruh signifikan terhadap loyalitas.
Kuusik et al., (2009) menyatakan bahwa kepercayaan merupakan salah satu faktor penting yang mempengaruhi loyalitas. Kepercayaan merupakan landasan untuk hubungan yang sukses dan langgeng dengan pelanggan. Kepercayaan dibangun ketika penyedia layanan tertarik dalam memuaskan kebutuhan pelanggan, dan menyediakan produk dan jasa yang menciptakan nilai pelanggan. Penelitian Chen dan Corkindale (2008) menemukan bahwa kepercayaan secara signifikan berpengaruh terhadap niat pembelian online, loyalitas penggunaan situs web, komitmen terhadap penggunaan perbankan online, adopsi perbankan elektronik dan niat perilaku untuk mengadopsi layanan informasi secara online. Kassim dan Abdullah (2006) menemukan bahwa untuk mengembangkan kepercayaan dan menarik lebih banyak pengguna untuk menggunakan layanan internet banking, tidak cukup hanya membuat sistem yang mudah untuk berinteraksi dengan layanan tersebut. Penting juga bagi bank untuk mengembangkan sistem layanan internet banking yang dapat dipercaya, aman, dan rahasia bagi pengguna.

Kemampuan bank untuk menyampaikan manfaat secara terus menerus akan memiliki dampak yang signifikan terhadap tingkat kepuasan pelanggan. Keinginan pelanggan untuk tetap setia dan membeli atau menggunakan jasa dari organisasi di masa depan tergantung pada seberapa puas pelanggan. Bontis et al., (2007) meneliti hubungan kausalitas antara kepuasan pelanggan dan loyalitas pelanggan industri perbankan di Amerika Utara dan menemukan bahwa ada hubungan positif antara kepuasan pelanggan dan loyalitas pelanggan. Penelitian Hafeez dan Muhammad (2012) dilakukan untuk mengetahui pengaruh kualitas pelayanan dan kepuasan pelanggan terhadap loyalitas pelanggan di sektor perbankan di Pakistan. Penelitian menunjukkan bahwa kualitas pelayanan, dan kepuasan pelanggan adalah faktor penting yang dapat meningkatkan loyalitas pelanggan terhadap bank. 


\section{HIPOTESIS}

Berdasarkan kajian teori yang digunakan dalam penelitian ini, maka kerangka penelitian dirumuskan berdasarkan konstruk berikut: kualitas layanan, persepsi nilai, kepercayaan, kepuasan konsumen dan loyalitas konsumen. Enam hipotesis dirumuskan berdasarkan konstruk sebagai berikut: $\mathrm{H}_{1}$ : Kualitas layanan berpengaruh terhadap kepuasan konsumen pengguna mobile banking.

$\mathrm{H}_{2}$ : Persepsi nilai berpengaruh terhadap kepuasan konsumen pengguna mobile banking.

$\mathrm{H}_{3}$ : Kepercayaan berpengaruh terhadap kepuasan konsumen pengguna mobile banking.

$\mathrm{H}_{4}$ : Kualitas layanan berpengaruh terhadap loyalitas pengguna mobile banking.

$\mathrm{H}_{5}$ : Persepsi nilai berpengaruh terhadap loyalitas pengguna mobile banking.

$\mathrm{H}_{6}$ : Kepercayaan berpengaruh terhadap loyalitas pengguna mobile banking.

$\mathrm{H}_{7}$ : Kepuasan konsumen berpengaruh terhadap loyalitas pengguna mobile banking.

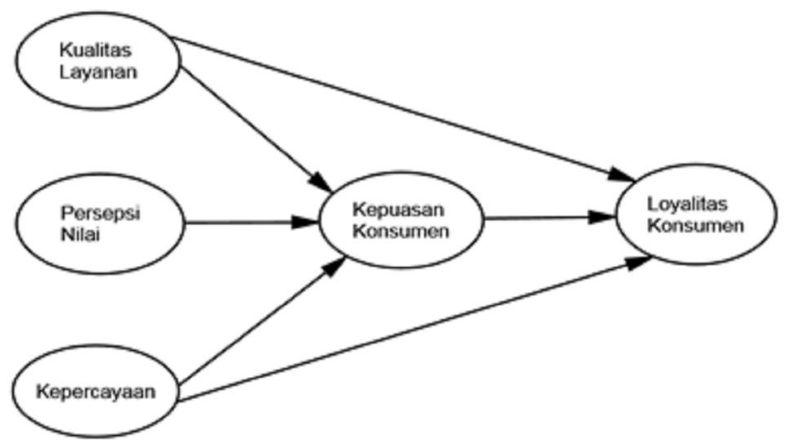

Gambar 1. Hipotesis Penelitian

\section{METODE}

Penelitian ini menggunakan pendekatan kuantitatif dengan menggunakan angka, mulai dari pengumpulan data, penafsiran data, serta pembahasan dari hasil analisisnya. Jenis penelitian ini merupakan penelitian kausal, yaitu penelitian yang menunjukkan hubungan sebab-akibat antara variabel independen terhadap variabel dependen selain mengukur kekuatan hubungan antara variabel-variabel tersebut dengan melalui pengujian hipotesis.

Populasi dalam penelitian ini adalah pengguna mobile banking di tujuh bank yang ada di kota Palembang, yaitu Bank Mandiri, Bank BNI, Bank BRI, Bank Danamon, Bank BCA, Bank Mega dan Bank Permata. Sampel adalah sebagian dari populasi yang memiliki karakteristik yang relatif sama dan dianggap dapat mewakili populasi. Hair et al., (1995, dalam Ferdinand 2006) menemukan bahwa ukuran sampel yang sesuai adalah antara 100 sampai 200. Juga dijelaskan bahwa ukuran sampel minimum adalah sebanyak 5 observasi untuk setiap estimated parameter dan maksimal adalah 10 observasi dari setiap estimated parameter. Dalam penelitian ini, jumlah indikator penelitian sebanyak 20 sehingga jumlah sampel adalah 10 kali jumlah indikator atau sebanyak $10 \times 20=200$.

Sampel penelitian sebanyak 200 responden dengan ketentuan pemilihan terhadap pengguna mobile banking di Kota Palembang dengan pertimbangan-pertimbangan tertentu. Metode penelitian yang digunakan dalam penelitian ini adalah metode survei. Metode survei merupakan metode pengumpulan data yang didasarkan pada pertanyaan yang disampaikan kepada responden yang didesain untuk mendapatkan informasi dari responden (Malhotra dan Dash, 2009). Prosedur pengumpulan data yang digunakan dalam penelitian ini adalah pengumpulan data tersetruktur (structured data collection) melalui kuesioner yang menyajikan pertanyaan yang telah disusun secara teratur terlebih dahulu.

Penelitian ini menggunakan model persamaan struktural (SEM) untuk menguji hipotesis penelitian dan menggunakan perangkat lunak AMOS 5.0 dan SPSS 20.0 untuk menganalisis uji reliabilitas dan uji validitas. Instrumen penelitian dapat di katakan valid jika $r$ hitung $>r$ tabel dan 


\section{Jurnal Keuangan dan Perbankan | PERBANKAN}

Vol. 20, No.3, September 2016: 518- 528

bernilai positif (Ghozali, 2005). Suatu instrumen penelitian dikatakan reliabel bila nilainya lebih besar dari tingkat yang dapat diterima yaitu 0,7 untuk semua item (Nunnally, 1978). Goodness of fit dari model pengukuran dievaluasi dengan menggunakan berbagai indeks. Untuk menilai konvergen dan diskriminan validitas, penelitian ini menggunakan model fit, signifikansi statistik dari masing-masing koefisien jalur.

\section{HASIL}

Uji validitas data dilakukan dengan Pearson Correlation untuk menguji korelasi setiap variabel penelitian. Adapun hasil uji validitas di jelaskan pada tabel 1.

Hasil uji validitas menunjukkan bahwa setiap variabel menunjukkan hasil yang signifikan (lebih kecil dari level 0,05). Jadi dapat disimpulkan bahwa setiap indikator pertanyaan yang digunakan di dalam instrumen penelitian adalah valid.

Uji reliabilitas digunakan untuk mengetahui tingkat kehandalan suatu instrumen penelitian dengan menggunakan rumus Cronbach Alpha (á). Suatu konstruk atau variabel dikatakan handal, jika nilai Cronbach Alpha > 0,70. Hasil analisis menunjukkan bahwa nilai Cronbach Alpha untuk setiap instrumen yang digunakan dalam penelitian ini menunjukkan nilai $>0,70$, artinya instrumen dalam penelitian ini adalah handal.

Nilai probabilitas sebesar 0,314 dimana nilai tersebut diatas 0,05. Nilai CMIN/DF sebesar 1,211 sehingga masih dibawah 2,00. Nilai GFI sebesar 0,921 lebih besar dari 0,90. AGFI sebesar 0,991 lebih besar dari 0,90. Nilai TLI sebesar 0,971 dimana masih di atas 0,95. Nilai CFI sebesar 0,963 dimana nilainya masih di atas 0,95 dan nilai RMSEA sebesar 0,026 yang mana nilai tersebut masih di bawah 0,08 . Hasil tersebut menunjukkan bahwa konstruk memenuhi kriteria model fit (Goodness ofFit Indices). Indikator dari konstruk kualitas layanan, persepsi nilai dan kepercayaan valid karena mempunyai nilai louding $\mathrm{d}$ atas 0,5 sehingga tidak satupun indikator yang dibuang. Hasil tersebut menunjukkan konstruk dapat diolah dengan full model.

Tabel 1. Hasil Uji Validitas Variabel Penelitian

\begin{tabular}{lccccc}
\hline \multicolumn{1}{c}{ Variabel } & $\begin{array}{c}\text { Kualitas } \\
\text { Layanan }\end{array}$ & $\begin{array}{c}\text { Persepsi } \\
\text { Nilai }\end{array}$ & Kepercayaan & $\begin{array}{c}\text { Kepuasan } \\
\text { Konsumen }\end{array}$ & $\begin{array}{c}\text { Loyalitas } \\
\text { Konsumen }\end{array}$ \\
\hline Kualitas Layanan & 1.000 & $.482^{* *}$ & $.419^{* *}$ & $.472^{* *}$ & $.506^{* *}$ \\
Persepsi Nilai & $.482^{* *}$ & 1.000 & $.467^{* *}$ & $.499^{* *}$ & $.493^{* *}$ \\
Kepercayaan & $.419^{* *}$ & $.467^{* *}$ & 1.000 & $.536^{* *}$ & $.229^{* *}$ \\
Kepuasan Konsumen & $.472^{* *}$ & $.499^{* *}$ & $.536^{* *}$ & 1.000 & $.553^{* *}$ \\
Loyalitas Konsumen & $.506^{* *}$ & $.493^{* *}$ & $.553^{* *}$ & $.732^{* *}$ & 1.000 \\
\hline
\end{tabular}

Sumber: data olahan, 2015

Tabel 2. Hasil Uji Reliabilitas Variabel Penelitian

\begin{tabular}{lcc}
\hline \multicolumn{1}{c}{ Variabel } & Number of Item & Nilai Alpha \\
\hline Kualitas Layanan & 3 & 0.829 \\
Persepsi Nilai & 2 & 0.884 \\
Kepercayaan & 5 & 0.715 \\
Kepuasan Konsumen & 5 & 0.809 \\
Loyalitas Konsumen & 5 & 0.908 \\
\hline
\end{tabular}

Sumber: data olahan, 2015 
Berdasarkan hasil pengolahan data setiap indikator atau dimensi pembentuk setiap variabel laten menunjukkan hasil yang memenuhi kriteria yaitu nilai Critical Ratio (CR) $>1.96$ dengan probability (P) lebih kecil dari pada 0,05. Berdasarkan hasil ini, maka dapat dikatakan bahwa indikator-indikator pembentuk variabel laten telah menunjukkan unidimensionalitas atau kumpulan dimensi konfirmatori faktor betul terjadi unidimensi antara indikator pembentuk suatu serangkaian yang tidak dapat dipisahkan. Nilai probabilitas sebesar 0,342 dimana nilai tersebut diatas 0,05 . Nilai CMIN/DF sebesar 1,243 sehingga masih dibawah 2,00. Nilai GFI sebesar 0,942 lebih besar dari 0,90. AGFI sebesar 0,954 lebih besar dari 0,90. Nilai TLI sebesar 0,968 dimana masih di atas 0,95. Nilai CFI sebesar 0,967 dimana nilainya masih di atas 0,95 dan nilai RMSEA sebesar 0,035 yang mana nilai tersebut masih di bawah 0,08.

Hasil tersebut menunjukkan bahwa konstruk memenuhi kriteria model fit (Goodness of-Fit Indices). Disamping kriteria diatas indikator dari konstruk kepuasan konsumen dan loyalitas konsumen valid karena mempunyai nilai louding $\mathrm{d}$ atas 0,5 sehingga tidak satupun indikator yang dibuang. Hasil tersebut menunjukkan konstruk dapat diolah dengan full model. Berdasarkan hasil pengolahan data setiap indikator atau dimensi pembentuk masing-masing variabel laten menunjukkan hasil yang memenuhi kriteria yaitu nilai Critical Ratio (CR) >1.96 dengan Probability (P) lebih kecil dari pada 0,05 . Berdasarkan hasil ini, maka dapat dikatakan bahwa indikator-indikator pembentuk variabel laten telah menunjukkan unidimensionalitas atau kumpulan dimensi konfirmatori faktor endogen betul terjadi undimensi antara indikator pembentuk suatu serangkaian yang tidak dapat dipisahkan.

Analisis selanjutnya adalah analisis Structural Equation Model (SEM) secara Full Model yang dimaksudkan untuk menguji model dan hipotesis yang dikembangkan dalam penelitian ini. Pengujian model dalam Structural Equation Model dilakukan dengan dua pengujian, yaitu uji kesesuaian model dan uji signifikansi kausalitas melalui uji koefisien regresi.

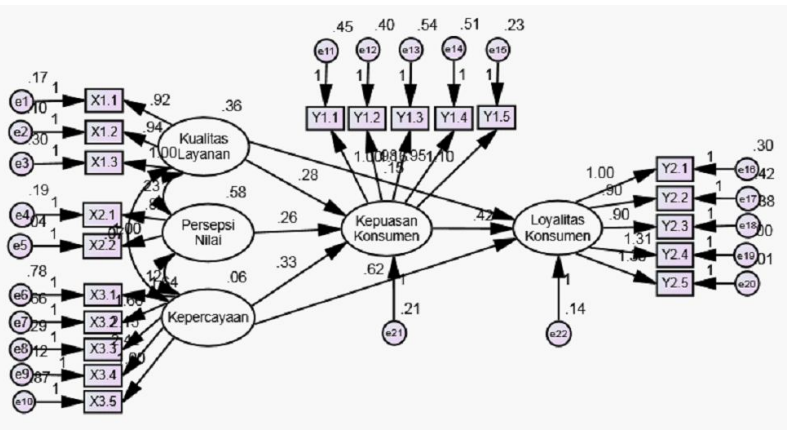

Gambar 2. Hasil Uji Structural Equation Model

Tabel 3. Hasil Uji Model

\begin{tabular}{lccc}
\hline Kriteria & Cut-off Value & Hasil & Evaluasi \\
\hline $\mathrm{X}^{2}$ - Chi Square & Diharapkan kecil & 267,012 & Baik \\
Probability & $>0.05$ & 0,497 & Baik \\
RMSEA & $<0.08$ & 0,042 & Baik \\
GFI & $>0.90$ & 0,928 & Baik \\
AGFI & $>0.90$ & 0,946 & Baik \\
CMIN/DF & $<2.00$ & 1,537 & Baik \\
TLI & $\geq 0.95$ & 0,976 & Baik \\
CFI & $>0.95$ & 0,954 & Baik \\
\hline
\end{tabular}

Sumber: data olahan, 2015 


\section{Jurnal Keuangan dan Perbankan | PERBANKAN}

Vol. 20, No.3, September 2016: 518- 528

Berdasarkan hasil pengamatan pada gambar pada grafik analisis full model dapat ditunjukkan bahwa model memenuhi kriteria fit, hal ini ditandai dengan nilai dari hasil perhitungan memenuhi kriteria layak full model.

Nilai probabilitas sebesar 0,497 dimana nilai tersebut di atas 0,05 . Nilai CMIN/DF sebesar 1,537 sehingga masih dibawah 2,00. Nilai GFI sebesar 0,928 yaitu lebih kecil dari 0,90, nilai AGFI sebesar 0,946 yaitu lebih besar dari 0,90 . Nilai TLI sebesar 0,976 dimana masih di atas 0,95. Nilai CFI sebesar 0,954 dimana nilainya masih di atas 0,95 dan nilai RMSEA sebesar 0,042 dimana nilai tersebut masih di bawah 0,08. Hasil tersebut menunjukkan bahwa model keseluruhan memenuhi kriteria model fit. Disamping kriteria diatas indikator dari konstruk adalah valid karena mempunyai nilai di atas 0,5 sehingga tidak satupun indikator yang dihilangkan.

Pengujian hipotesis pada penelitian dilakukan dengan cara melihat jalur-lajur pada model persamaan struktural. Untuk mengetahui jalur-jalur hubungan yang signifikan dapat dilihat pada uji koefisien jalur. Hasil uji terhadap koefisien jalur pada setiap jalur dapat dilihat pada tabel berikut ini.

Tabel 4. Hasil Regression Weights Analisis Structural Equation Modeling

\begin{tabular}{|c|c|c|c|c|c|c|}
\hline & & & Estimate & S.E. & C.R. & $\mathrm{P}$ \\
\hline Kepuasan_Konsumen & $<--$ & Persepsi_Nilai & .264 & .082 & 3.211 & .001 \\
\hline Kepuasan_Konsumen & $<--$ & Kepercayaan & .334 & .063 & 3.271 & .004 \\
\hline Kepuasan_Konsumen & $<--$ & Kualitas_Layanan & .280 & .090 & 3.108 & .002 \\
\hline Loyalitas_Konsumen & $<--$ & Kepuasan_Konsumen & .421 & .083 & 5.079 & $* * *$ \\
\hline Loyalitas_Konsumen & $<--$ & Persepsi_Nilai & .279 & .093 & 3.106 & .001 \\
\hline Loyalitas_Konsumen & $<--$ & Kepercayaan & .622 & .242 & 2.573 & .010 \\
\hline Loyalitas_Konsumen & $<--$ & Kualitas_Layanan & .145 & .068 & 2.142 & .032 \\
\hline $\mathrm{X} 1.3$ & $<--$ & Kualitas_Layanan & 1.000 & & & \\
\hline$X 1.2$ & $<---$ & Kualitas_Layanan & .943 & .085 & 11.062 & $* * *$ \\
\hline X1.1 & $<--$ & Kualitas_Layanan & .918 & .087 & 10.580 & $* * *$ \\
\hline X2.1 & $<--$ & Persepsi_Nilai & .825 & .065 & 12.756 & $* * *$ \\
\hline X3.3 & $<--$ & Kepercayaan & 2.151 & .641 & 3.354 & $* * *$ \\
\hline Y2.1 & $<--$ & Loyalitas_Konsumen & 1.000 & & & \\
\hline Y2.2 & $<--$ & Loyalitas_Konsumen & .899 & .104 & 8.668 & $* * *$ \\
\hline Y2.3 & $<--$ & Loyalitas_Konsumen & .897 & .101 & 8.898 & $* * *$ \\
\hline Y2.4 & $<---$ & Loyalitas_Konsumen & 1.313 & .092 & 14.268 & $* * *$ \\
\hline Y2.5 & $<--$ & Loyalitas_Konsumen & 1.303 & .091 & 14.243 & $* * *$ \\
\hline$X 2.2$ & $<--$ & Persepsi_Nilai & 1.000 & & & \\
\hline X3.4 & $<--$ & Kepercayaan & 2.419 & .711 & 3.404 & $* * *$ \\
\hline $\mathrm{X} 3.2$ & $<--$ & Kepercayaan & 1.656 & .538 & 3.078 & .002 \\
\hline X3.1 & $<--$ & Kepercayaan & 1.645 & .546 & 3.012 & .003 \\
\hline X3.5 & $<--$ & Kepercayaan & 1.000 & & & \\
\hline Y1.2 & $<--$ & Kepuasan_Konsumen & 1.155 & .132 & 8.729 & $* * *$ \\
\hline Y1.1 & $<---$ & Kepuasan_Konsumen & 1.000 & & & \\
\hline Y1.3 & $<--$ & Kepuasan_Konsumen & .978 & .129 & 7.570 & $* * *$ \\
\hline Y1.4 & $<--$ & Kepuasan_Konsumen & .947 & .125 & 7.555 & $* * *$ \\
\hline Y1.5 & $<--$ & Kepuasan_Konsumen & 1.097 & .118 & 9.318 & $* * *$ \\
\hline
\end{tabular}

Sumber: data olahan, 2015 


\section{PEMBAHASAN}

Hasil analisis data menunjukkan bahwa variabel kualitas layanan berpengaruh signifikan terhadap kepuasan konsumen. Ini ditunjukkan dari nilai CR sebesar 3.108 dan probabilitas signifikansinya 0.002 lebih kecil dari taraf signifikansi $(\alpha)$ yang ditentukan yaitu $\leq 0.05$. Hipotesis penelitian yang menyatakan bahwa kualitas layanan berpengaruh signifikan terhadap kepuasan konsumen terbukti (diterima) sebesar 28\%. Penelitian ini mendukung penelitian Khan dan Fasih (2014) yang menyatakan bahwa kualitas pelayanan dan semua dimensi memiliki signifikan dan positif hubungan dengan kepuasan pelanggan. Peningkatan kualitas pelayanan bank dapat memuaskan dan mengembangkan sikap loyalitas yang akhirnya mempertahankan pelanggan yang berharga. Semakin tinggi tingkat hasil kualitas pelayanan yang dirasakan maka akan meningkatkan kepuasan pelanggan. Ketika kualitas pelayanan yang dirasakan kurang dari yang diharapkan maka pelanggan akan merasa tidak puas.

Variabel persepsi nilai berpengaruh signifikan terhadap kepuasan konsumen. Ini ditunjukkan dari nilai CR sebesar 3.211 dan probabilitas signifikansinya 0.001 lebih kecil dari taraf signifikansi $(\alpha)$ yang ditentukan yaitu $\leq 0.05$. Hipotesis penelitian yang menyatakan bahwa persepsi nilai berpengaruh signifikan terhadap kepuasan konsumen terbukti (diterima) sebesar $26,4 \%$. Penelitian ini mendukung penelitian Malik (2012) yang menyatakan bahwa persepsi nilai berpengaruh kepuasan pelanggan. Bank seharusnya tidak hanya mempertimbangkan untuk meningkatkan kepuasan pelanggan tetapi juga menargetkan pada peningkatan persepsi pelanggan tentang kualitas layanan secara keseluruhan dan harus meningkatkan perspei nilai dari konsumen. Selain itu, bank harus mampu memberikan keyakinan bahwa pelanggan akan mendapatkan nilai yang tinggi dari fasilitas pelayanan bank.

Variabel kepercayaan berpengaruh signifikan terhadap kepuasan konsumen. Ini ditunjukkan dari nilai CR sebesar 3.271 dan probabilitas signifikansinya 0.004 lebih kecil dari taraf signifikansi $(\alpha)$ yang ditentukan yaitu $\leq 0.05$. Hipotesis penelitian yang menyatakan bahwa kepercayaan berpengaruh signifikan terhadap kepuasan konsumen terbukti (diterima) sebesar 33,4\%. Penelitian ini mendukung penelitian Aydin dan Ozer (2005); Du Plessis (2010) yang menyatakan bahwa kepercayaan merupakan faktor penting dalam mempengaruhi pembentukan komitmen hubungan dan kepuasan pelanggan. Kepercayaan pelanggan yang kuat akan memungkinkan pelanggan untuk yakin tentang penyedia layanan di masa depan. Kepercayaan mempengaruhi persepsi pelanggan dari keselarasan nilai dengan penyedia layanan, yang secara signifikan berhubungan dengan kepuasan pelanggan.

Tabel 5. Koefisien Jalur, CR dan Probalilitas Signifikansi Hasil Pengujian Variabel Penelitian

\begin{tabular}{lcccc}
\hline \multicolumn{1}{c}{ Jalur } & $\begin{array}{c}\text { Koefisien } \\
\text { Jalur }\end{array}$ & CR & P & Keterangan \\
\hline Kepuasan_Konsumen <--- Persepsi_Nilai & 0.264 & 3.211 & 0.001 & Signifikan \\
Kepuasan_Konsumen<--- Kepercayaan & 0.334 & 3.271 & 0.004 & Siginifikan \\
Kepuasan_Konsumen<--- Kualitas_Layanan & 0.280 & 3.108 & 0.002 & Signifikan \\
Loyalitas_Konsumen<--- Kepuasan_Konsumen & 0.421 & 5.079 & 0.000 & Signifikan \\
Loyalitas_Konsumen<--- Persepsi_Nilai & 0.279 & 3.106 & 0.001 & Signifikan \\
Loyalitas_Konsumen<--- Kepercayaan & 0.622 & 2.573 & 0.001 & Signifikan \\
Loyalitas_Konsumen<--- Kualitas_Layanan & 0.145 & 2.142 & 0.032 & Signifikan \\
\hline
\end{tabular}

Sumber: data olahan, 2015 


\section{Jurnal Keuangan dan Perbankan | PERBANKAN}

Vol. 20, No.3, September 2016: 518- 528

Variabel kualitas layanan berpengaruh signifikan terhadap loyalitas konsumen. Ini ditunjukkan dari nilai CR sebesar 2.142 dan probabilitas signifikansinya 0.032 lebih kecil dari taraf signifikansi $(\alpha)$ yang ditentukan yaitu $\leq 0.05$. Hipotesis penelitian yang menyatakan bahwa kualitas layanan berpengaruh signifikan terhadap loyalitas konsumen terbukti (diterima) sebesar 14,5\%. Penelitian ini mendukung penelitian yang dilakukan oleh Aliabadi et al., (2013) yang menyatakan bahwa ada hubungan yang signifikan dan positif antara kualitas layanan dan Loyalitas. Adanya hubungan antara kualitas layanan dan retensi pelanggan pada tingkat yang lebih tinggi menunjukkan bahwa kualitas pelayanan memiliki dampak pada perilaku konsumen, di mana kualitas layanan yang unggul mengarah ke niat perilaku yang menguntungkan yaitu loyalitas pelanggan, sementara niat perilaku yang tidak menguntungkan adalah konsekuensi dari kualitas pelayanan rendah.

Variabel persepsi nilai berpengaruh signifikan terhadap loyalitas konsumen. Ini ditunjukkan dari nilai CR sebesar 3.106 dan probabilitas signifikansinya 0.001 lebih kecil dari taraf signifikansi $(\alpha)$ yang ditentukan yaitu $\leq 0.05$. Hipotesis penelitian yang menyatakan bahwa persepsi nilai berpengaruh signifikan terhadap loyalitas konsumen terbukti (diterima) sebesar 27,9\%. Penelitian ini mendukung penelitian Park et al., (2006) yang menemukan bahwa konsumen selalu mempertimbangkan nilai uang yang dikeluarkan dalam memutuskan apakah akan kembali menggunakan penyedia layanan atau tidak. Persepsi nilai pelanggan berkaitan dengan layanan diberikan oleh bankbank komersial sehingga akan mempengaruhi loyalitas konsumen. Ini berarti bahwa loyalitas sangat tergantung pada persepsi nilai pelanggan terhadap layanan yang diberikan oleh bank. Semakin tinggi persepsi nilai pelanggan seperti persepsi kualitas pelayanan, keamanan pelanggan dan keyakinan akan meningkatkan tingkat loyalitas pelanggan terhadap bank.

Variabel kepercayaan berpengaruh signifikan terhadap loyalitas konsumen. Ini ditunjukkan dari nilai CR sebesar 2.573 dan probabilitas signifikansinya 0.010 lebih kecil dari taraf signifikansi $(\alpha)$ yang ditentukan yaitu $\leq 0.05$. Hipotesis penelitian yang menyatakan bahwa kepercayaan berpengaruh signifikan terhadap loyalitas konsumen terbukti (diterima) sebesar 62,2\%. Penelitian ini mendukung penelitian Hasan et al., (2014); Kim dan Benbasat, 2003; yang menyatakan bahwa kepercayaan ini memiliki hubungan yang positif dan signifikan dengan loyalitas pelanggan yang diterima sebagai kepercayaan yang tinggi terhadap bank. Semakin besar kepuasan pelanggan dengan suatu bank karena produk yang dibeli atau kualitas layanan, semakin besar kepercayaan pelanggan terhadap bank tersebut.

Variabel kepuasan konsumen berpengaruh signifikan terhadap loyalitas konsumen. Ini ditunjukkan dari nilai CR sebesar 5.079 dan probabilitas signifikansinya 0.000 lebih kecil dari taraf signifikansi $(\alpha)$ yang ditentukan yaitu $\leq 0.05$. Hipotesis penelitian yang menyatakan bahwa kepuasan konsumen berpengaruh signifikan terhadap loyalitas konsumen terbukti (diterima) sebesar $42,1 \%$. Penelitian ini mendukung penelitian yang dilakukan oleh Hasan et al., (2013) yang menyatakan bahwa terdapat korelasi positif dan kuat antara kepuasan pelanggan dengan loyalitas pelanggan. Pelanggan yang puas akhirnya menjadi loyal dengan bank, dan akan menjadi sarana bagi bank untuk berpromosi ke pihak lain. Mereka memberikan referensi kepada orang lain untuk melakukan bisnis dengan bank. Oleh karena itu, bank dapat mengurangi biaya dari iklan serta membangun hubungan bisnis jangka panjang dengan konsumen.

\section{KESIMPULAN}

Penelitian ini memberikan bukti empiris yang mendukung hubungan antara kualitas layanan, persepsi nilai, kepercayaan, kepuasan pelanggan dan loyalitas nasabah bank. Pada saat yang sama, penelitian ini juga memberikan dukungan empiris untuk teori Tripartite Attitude Model: Cognitive-Af- 
fective-Conative. Pada penelitian ini, kualitas layanan, persepsi nilai dan kepercayaan merupakan komponen kognisi yang membentuk persepsi positif terhadap bank. Kepuasan pelanggan adalah komponen afektif yang membentuk perasaan positif konsumen terhadap produk dan jasa bank. Loyalitas pelanggan adalah komponen konatif di mana pelanggan akan memiliki niat untuk menggunakan layanan bank dalam jangka panjang.

Hasil penelitian menunjukkan bahwa kualitas layanan, persepsi nilai, kepercayaan dan kepuasan pelanggan memiliki efek yang kuat dan berpengaruh terhadap loyalitas pelanggan bank. Saat ini penting bagi bank untuk memahami faktorfaktor yang mempengaruhi loyalitas pelanggan dan proses pengembangan loyalitas pelanggan, manajemen hubungan pelanggan, bagaimana meningkatkan kepuasan pelanggan dan loyalitas pelanggan sebagai dasar keunggulan kompetitif perusahaan. Pelaksanaan program loyalitas pelanggan penting untuk mempertahankan portofolio yang ada karena biaya untuk memperoleh pelanggan baru selalu lebih tinggi.

\section{SARAN}

Bank harus membangun hubungan yang kuat dengan pelanggan dan memberikan kualitas layanan yang lebih baik untuk mengurangi perilaku pelanggan untuk beralih ke layanan bank lain. Penelitian ini menunjukkan bahwa jika pelanggan puas dan bahagia, dan dengan asumsi bahwa produk dan layanan perbankan yang diterima oleh pelanggan adalah terukur dan menawarkan nilai kompetitif, pelanggan kemudian akan tetap setia kepada bank untuk jangka panjang.

\section{DAFTAR PUSTAKA}

Aliabadi, Bahareh Moradi. Shidinavid, Babakjam. \& Namamian, Farshid. 2013. Design and Explain the Factors Affecting Customer Loyalty in Online Banking, International Research Journal of Applied and Basic Sciences, 4 (9): 2782-2791.
Anderson \& Srinivasan. 2003. E-Satisfaction and E-Loyalty: A Contingency Framework, Psychology $\mathcal{E}$ Marketing, 20 (2): 123-138.

Atalik O. \& Arslan M. 2009. A Study to Determine the Effects of Customer Value on Customer Loyalty in Airline Companies Operating: Case of Turkish Air Travelers, International Journal of Business and Management, 4 (6): 154-162.

Aydin, S. \& Ozer, G. 2005. The Analysis of Antecedents of Customer Loyalty in the Turkish Mobile Telecommunication Market, European Journal of Marketing, 39, (7): 910-925.

Bontis, Nick. Booker, Lorne D. \& Serenko, A. 2007. The Mediating Effect of Organizational Reputation on Customer Loyalty and Service Recommendation in the Banking Industry, Management Decision, 45 (9): 1425-1445.

Chen, Y. H \& Corkindale, D. 2008. Towards an Understanding of the Behavioral Intention to Use Online News Services An Exploratory Study, Mobile Research, 18 (3): 286-312.

Cronin, J. \& A, Taylor. 1992. Measuring Service Quality: A Reexamination and Extension, Journal of Marketing, 56 (3): 55-58.

Du Plessis, L. 2010. Customer Relationship Management and its Influence on Customer Loyalty. Liberty Life in South Africa. University of Johannesburg.

Ferdinand, Augusty. 2006. Metode Penelitian Manajemen: Pedoman Penelitian untuk skripsi, Tesis dan Disertai Ilmu Manajemen. Semarang: Universitas Diponegoro.

Ghozali, Imam. 2005. Aplikasi Analisis Multivariate dengan Program SPSS, Semarang, Badan Penerbit Universitas Diponegoro.

Hafeez, Samraz. \& Muhammad, Bakhtiar. 2012. The Impact of Service Quality, Customer Satisfaction and Loyalty Programs on Customer's Loyalty: Evidence from Banking Sector of Pakistan, International Journal of Business and Social Science, 3 (16): 200-209.

Hair JF., Anderson RE, Tatham RL., \& Black WC. 1995, Multivariate Data Analysis, Fourth ed. New Jersey: Prentice Hall.

Hasan, Haslinda. Kiong, Teo Poh. \& Ainuddin, Raja Azimah. 2014. Effects of Perceived Value and Trust 


\section{Jurnal Keuangan dan Perbankan | PERBANKAN}

Vol. 20, No.3, September 2016: 518- 528

on Customer Loyalty towards Foreign Banks in Sabah, Malaysia, Global Journal of Emerging Trends in e-Business, Marketing and Consumer Psychology, 1 (2): 137-153

Hassan, Ul Masood. Malik, Ayaz Ahmad. Imran, Muhammad. Hasnain, Amna. \& Abbas, Javaria. 2013. Relationships among Customers' Perceived Service Quality, Satisfaction and Loyalty in the Retail Banking Sector of Pakistan, World Applied Sciences Journal, 24 (8): 1020-1030.

Kassim, N. M. \& Abdullah, A. K. M. A. 2006. The Influence of Attraction on Internet Banking: An Extension to the Trust Relationship Commitment Model, International Journal of Bank Marketing, 24 (6): 424442.

Khan, Mubbsher Munawar. \& Fasih, Mariam. 2014. Impact of Service Quality on Customer Satisfaction and Customer Loyalty: Evidence from Banking Sector, Pakistan Journal of Commerce and Social Science, 8 (2): 331- 354.

Kim, D. \& Benbasat, I. 2003. Trust-related arguments in Internet stores: a framework for evaluation, Journal of Electronic Commerce Research, 4 (2): 49-64.

Kuo, Y. Wu, C. \& Deng, W. 2009. The relationships among service quality, perceived value, customer satisfaction and post-purchase intention in mobile value-added services. Computers in Human Behavior, 25: 887-896.

Kuusik, A. \& Varblane, U. 2009. How to avoid customers leaving: the case of the Estonian telecommunication industry, Baltic Journal of Management, 4 (1): 66-79.
Malhotra, Naresh K. \& Satyabhushan, Dash. 2009. Marketing Research: An Applied Orientation. Fifth Edition. New Delhi: Dorling Kindersley (India) Pvt. Ltd. Licences of Pearson Education in South Asia.

Malik, Saif Ullah. 2012. Customer Satisfaction, Perceived Service Quality and Mediating Role of Perceived Value, International Journal of Marketing Studies, 4, (1): 68-76.

Nunnally, J. 1978. Psychometric Theory, 2nd Ed. New York: McGraw-Hill

Park, J. Robertson. R. \& Wu, C. 2006. Modelling The Impact of Airline Service Quality and Marketing Variables on Passengers' Future Behavioural Intentions, Transportation Planning and Technology, 29 (5): 359-381.

Roig, J.C.F. Garcia, J.S. Tena, M.A.M. \& Monzonis, J.L. 2006. Customer Perceived Value in Banking Services, International Journal of Bank Marketing, 24 (5): 266-83.

Sirdeshmukh, D. Singh, J. \& Sabol, B. 2002. Customer Trust, Value, and Loyalty in Relational Exchanges, Journal of Marketing, 66: 15-37.

Zeithaml, V. A. Berry, L. L. \& Parasuraman, A. 1996. The Behavioral Consequences of Service Quality, Journal of Marketing, 60 (2): 31-46. 